\title{
Regional and Local Devolution in Ireland - the Potential of LEADER Partnerships to Provide Municipal Government
}

\author{
BRENDAN O'KEEFFE
}

\begin{abstract}
Emerging economic and social challenges prompted EU and national authorities to initiate and support localised or area-based partnership approaches to development. Such approaches involve enabling representatives from the state sector, social partners, community and voluntary groups to form collaborative partnership structures with competences in integrated local development in a defined geographical area. In terms of local development in Ireland, the most significant partnership structures that have emerged are LEADER Local Action Groups and Local Development Partnerships. Extensive studies of partnership processes, outputs and limitations in Ireland and throughout the EU reveal a number of limitations in the current degree of synergy between partnership and mainstream approaches. Emerging development approaches to the provision of social welfare and public services increasingly involve new forms of public-voluntary and public-private partnerships.
\end{abstract}

KEY WORDS: • regional and local devolution $\bullet$ Ireland $\bullet$ EU $\bullet$ areabased partnership approach - local development $\bullet$ partnership structures • LEADER • rural development • local development partnership $\bullet$ social welfare

Correspondence Address: Brendan O'Keeffe, Ph.D, Mary Immaculate College, South Circular Road, Limerick, Ireland, e-mail: brendan.okeeffe@mic.ul.ie. 


\section{Introduction}

The demonstrated ability of National Social Partnership arrangements in countries such as Austria and Sweden over many decades, and in Ireland since the late 1980s, to provide effective responses to emerging economic and social challenges, prompted EU and national authorities to initiate and support localised or areabased partnership approaches to development. Such approaches involve enabling representatives from the state sector, social partners and community and voluntary groups to form collaborative partnership structures with competencies in integrated local development in a defined geographical area. In terms of local development in Ireland, the most significant partnership structures that have emerged are LEADER ${ }^{1}$ Local Action Groups and Local Development Partnerships.

The emergence of partnership processes as a feature of local governance in Ireland was very gradual and incremental and at times, it has been fraught with difficulty. Initially, the state sector was hostile towards endogenous and collective efforts on the part of the community and voluntary sector to address rural, local and regional development issues. Exogenous approaches dominated decision-making processes, and relationships between the statutory and community sectors tended to be characterised by mutual avoidance and distrust. However, by the 1980s, both the statutory and community sectors recognised the need for new approaches to regional and territorial development. The economic downturn of the 1970s and '80s associated with post-Fordist restructuring, promoted governments throughout Europe to consider localised and innovative approaches to promoting economic development and social cohesion. National and regional governments became increasingly aware of the potential of endogenous development, and several introduced area-based schemes and projects, with the objective of realising the value of endogenous resources.

At the level of the EU, initiatives such as the Anti-Poverty Programmes (19751994) represented an area-based and endogenous approach that involved collaboration between the state and community sectors in tackling poverty and unemployment in defined geographical areas. Experience of the Poverty Programmes and other state-funded initiatives such as the Pilot IRD Programme (1988-1990) brought the community and voluntary sector into more frequent and more constructive contact with the state. Both the state and community sectors recognised the mutual benefits that could accrue from joint-collaboration.

International trends towards partnership, the successful negotiation of the first National Social Partnership Agreement in 1987, emerging EU frameworks including the publication in 1988 of The White Paper; The Future of Rural Society and the introduction of regional development policies and funds at EU level, encouraged the Irish Government to commit to supporting area-based partnership 
structures. Domestic issues, including spiralling unemployment, poor industrial productivity, rising social deprivation and economic stagnation further increased the onus on government to consider alternative approaches to economic and social development. These factors and a NESC Report ${ }^{2}$, which encouraged government to adopt cross-sectoral and area-based approaches, as to harness the capacity of voluntary associations precipitates the establishment of the first PESP (Programme for Economic and Social Progress) area partnership companies. Their successes in delivering training and employment actions and the availability of EU funding in the form of a global grant led to the establishment of Area Partnership Companies throughout most of the West and North West of rural Ireland by 1993. Since 1991, the EU had supported the formation of sixteen LEADER Local Action Groups in Ireland, which were providing support to innovative community, social and enterprise development projects.

LEADER Partnerships together with the Local Development Partnerships supported by the state agency Pobal (formerly ADM - Area Development Management, an intermediary body established by the Government of Ireland and the European Commission) now operate in all parts of Ireland - eight in Dublin city, one each in the larger provincial cities and thirty-six in rural territories. These area-based partnerships are characterised by their tri-partite board structures, innovative actions, relatively high degrees of citizen participation in most cases and the ability to identify and articulate local needs and development potential. Local development partnerships are becoming increasingly concerned with addressing the contextual conditions that affect territorial development and partnership operation. The range of programmes operated by partnerships has expanded. Interfacing with the state sector is gaining increasing significance, and mainstreaming is becoming more prominent. Up to 2008, a number of anomalies existed in the respect of the geographical coverage and functional remit provided by Ireland's local development partnerships. Many parts of the country, particularly in the south and east lacked coverage by social inclusion partnerships (having had exclusively LEADER Partnerships), while in other areas, separate and often unconnected structures implemented either LEADER or Social Inclusion Programmes, and in some cases these parallel structures operated in the same territory. In order to align the functions and spatial remit of partnerships, the Department (National Ministry) of Community, Rural and Gaeltacht (Irish Language) Affairs spearheaded the process known as 'cohesion.' This has gradually achieved amalgamations of partnership boards in areas where functions had overlapped and it has led to the emergence of new partnership structures in other areas. In November 2008, the government announced an investment of $€ 424 \mathrm{~m}$ to enable partnerships in rural areas to implement the LEADER Programme up to 2013. This allocation represents more than a three-fold increase in the LEADER budget relative to the previous programme period (2000-2006). 


\section{Neo-Endogenous Partnership Processes}

Most partnerships in Ireland are firmly rooted within the communities where they work. Many were founded by community leaders coming together to pursue bottom-up / endogenous approaches to local problems. Producer co-operatives, small businesses and civil society leaders were the main drivers of partnership developments during the 1980s and early 1990s. Local leaders and champions have continued to play a valuable role in guiding and facilitating the growth and expansion of partnerships, and while their endogenous leanings remain a feature of Ireland's local partnerships, increasing levels of engagement in them by representatives from local government and state sector organisations suggest that partnerships occupy a governance space that cannot be classified as exclusively endogenous, but rather as neo-endogenous - seeking to deliver actions, coordinate activities and broker resources across a range of sectors, but with a firm focus on meeting the specific needs and developing the potential of a clearly identifiable locale.

The defining characteristics of partnerships include a tri-partite structure, with balanced representation from the statutory, social partner and community sectors. The effectiveness of partnerships is enhanced by power-sharing, decentralisation, subsidiarity, a sharing of responsibilities, joint-initiatives between the partners, attention to and investment in building the capacity of partners, and commitments to delivering agreed work programmes, which are subject to review and evaluation. Intra-partner dynamics involve elements of endogenous and exogenous approaches to development. They require partners to consult with the stakeholders, whom they represent. Negotiations, trade-offs and compromises are part and parcel of the decision-making process within partnership, which has the advantage of ensuring greater acceptance of decisions made, but the disadvantage of being cumbersome and time-consuming. Partnerships are required to be innovative, and to demonstrate the flexibility to respond to local needs and requirements in ways, which traditional exogenous bodies did not.

Since their commencement in the early 1990s, successive LEADER and Local Development Programmes have exceeded their targets in most areas. However, in delivering these programmes, the partnerships have increasingly come to realise the need to address broader structural issues, so that locales optimise their development potential and generate economic and social competitiveness.

Local Development Partnerships draw extensively on the experience and knowledge of citizens, and there is frequent interfacing between partnerships and citizens at community level through group structures and community networks. IRD Duhallow, a partnership based in the south west of Ireland (East County Kerry and North West County Cork) has attained a notably high level of citizen participation in all aspects of partnership decision making. Its Board of Directors 
comprises twenty-five members, with dedicated seats allocated to sociallyexcluded groups in society and local communities of interest such as cultural associations, youth, carers and a women's network. Moreover, IRD Duhallow has established thematic twelve working groups - thereby broadening the conduits through with local citizens, local government, the productive sector and statutory agencies can interface with one another and pursue collaborative ventures. These working groups, together with a number of community- based citizens' fora (representing community volunteers, women, smallholder farmers and youth) succeed in engaging over 4,500 people (in a territory with a population of 32,000 ) directly in local governance.

As part of the cohesion process, transitional governance arrangements have been prescribed for partnerships. However, as newer partnerships consolidate over the coming two to three years, and as the levels of activity generated by the new LEADER and upcoming social inclusion programmes lead to increased levels of local networking and collaboration, partnerships will need to adapt their governance composition to further enable a channelling of bottom-up energies and an animation of civil society as a well-organised and structured stakeholder in local economic development, social provision and environmental resource management.

Participation in partnership governance has influenced, and in some cases altered and enhanced the role of the state sector in local and rural development. Several state agencies have demonstrated a high degree of buy-in to the partnership processes. They have funded and co-funded projects in collaboration with the partnership itself and / or with social partners and community groups. While most agencies have progressively engaged in collaborative ventures, and have come to share power in partnership arrangements, a number of agencies do not. The case studies suggest that the role played by lead government departments shapes and influences the responses of agencies at the local level. The current variations among agencies in responding to partnership dynamics suggest the need for agencies to be given greater exogenous direction, competencies and resources in the interest of promoting their participation in partnerships.

Spatial variables emerge as a significant determinant of the effectiveness of partnership processes. Initiatives that operate in more homogeneous economic and social territories, and which respond to the specific characteristics and resource potential of locales are more effective in enhancing territorial competitiveness than are initiatives that operate on larger geographical scales, and which prioritise administrative divisions over economic, cultural, social and environmental realities. Administrative autonomy, a high degree of integration and the flexibility to respond to local conditions, and to target specific sub-areas and cohorts of the rural population add to the effectiveness of partnerships. The demarcation and promotion of functional planning and development areas in Ireland has been very 
much neglected heretofore. Drawing on the lessons from the case studies here, regional authorities ought to initiate such a process. Adherence to functional areas should be a requirement of future area-based partnership programmes, including the programmes that are expected to follow LEADER and the LDSIP (Local Development Social Inclusion Programme) from 2008. This area-based approach may then be rolled-out in the formation of municipal / communal / sub-county governance in Ireland.

\section{Evolving Local Governance in Ireland}

One of the distinguishing features of local development partnerships is their role in promoting community development, citizen-empowerment, collective and inclusive decision-making and the development of social capital (Scott, 2004: 4959; Walsh \& Meldon, 2004; OECD, 2001; OECD, 2005). The enhancement of participative democracy ranks among the leading achievements of the partnership. Their impact in facilitating citizen participation has been strongest at community level, where the numbers participating in development projects have increased considerably and where project implementation processes have become more inclusive. However, the extension of the practices associated with representative democracy does not apply completely or extensively to the partnerships themselves. While interfacing between locally-based participative structures and agents of the state has become more consultative, a number of issues are emerging that tend to inhibit the realisation of high-level vision participation.

Board directors and sub-committee members play a valuable role in identifying local needs, issues and volunteers. Moreover, the overwhelming evidence from empirical work is that adequate staff resources are essential in ensuring that partnerships promote participation in a way that is inclusive of all citizens. This thesis is supported by Fox (Fox, 2004) and Shucksmith (Shucksmith, 2004), who demonstrate that where community development approaches neglect or underresource capacity-building, networks and social capital can become exclusive, and social capital can be used to limit the supply of benefits in and to rural communities.

One of the tools applied by partnerships in stimulating citizen participation has been to work with existing community structures, and to enable them to expand their range of activities and by extension, their membership. The partnerships' work in addressing social exclusion underscores the need for a holistic approach to empowerment and progression. The provision of personal development and family supports can have a direct bearing on the ability of an individual to secure or hold on to employment, and/ or participate in local decision-making. The evidence from County Leitrim shows that CDPs (Community Development Projects) play a useful role in providing family supports. 
Consultations with community-based stakeholders in the course of case study research reveal that the community development landscape has become more complex in recent years, with the HSE (Health Services Executive) and CDBs (County Development Boards) deciding to recruit development officers, with community development briefs. While there is more than sufficient community work to be done in many areas, particularly in disadvantaged neighbourhoods and peripheral rural areas, some of the newer entrants to the community development field have tended to pay little attention to pre-existing structures. Interfacing between the statutory and community sectors is becoming more frequent and structured. Community sector participation in decision-making structures established under the aegis of the CDBs is to be welcomed. However, greater attention needs to be paid to ensuring gender and social class balance in the nominees to such structures.

Interfacing with local authorities is a significant part of the work of rural development partnerships. In general, co-operation has been positive, with a number of joint-projects emerging, particularly in the areas of village enhancement and estate management. Some partnerships such as Arigna LEADER (North Roscommon and County Leitirm) and IRD Duhallow (East Kerry) have had county council (local government) representatives on their Boards of Directors since their inceptions. Since 1999, all partnerships are obliged by national legislation to have elected local government councillors (politicians) on their boards. There was some unease initially that this move could lead to a politicisation of local development. Greer (Greer, 1999) noted that in Northern Ireland councillors had made limited contributions to partnerships due to commitments associated with council business and personnel changes following local government elections. However, six years after the introduction of this provision, the experience of the partnerships is universally positive. Partnership directors and management report that councillors are providing local leadership, and are facilitating contacts between partnerships and local authorities. Councillors report positively on their experience of the partnership structures, and many have become more vocal in advocating a more prominent developmental role for partnerships. Recently commenced pilot projects, which involve expanding local authority area committees, offer the potential to enhance cooperation between local government and local development.

\section{Territorial Impacts of Area-Based Partnerships in Ireland}

Partnership processes are adding significant value to the attainment of sustainable rural development goals. A number of case studies (O'Keeffe, 2006) provide tangible examples of the outputs and impacts of rural development partnerships. Neo endogenous partnerships enhance the territorial competitiveness of local territories and that, with some modifications, area-based, integrated and endogenous approaches to development have the potential to deliver a greater 
range of programmes and benefits to rural territories. As the following maps show, South Kerry Development Partnership (based in a peripheral part of the south-west of Ireland) has successfully delivered a range of economic development projects across its territory. Moreover, the Partnership has enabled the formation and growth of a number of civil society (community-based, voluntary) associations.

In general, partnerships' most significant contribution to area-based development is their animation and fostering of collective endogenous action that strengthens local identity, promotes positive perceptions of local territories and increases citizen participation in local governance. Citizen participation is incentivised by the promotive role of partnership staff and by the structure and focus on development deliverables made possible by autonomous and inclusive partnership boards and sub-committees. Funding provided by partnerships to enable community and voluntary groups to undertake development projects furthers citizen participation and local governance.

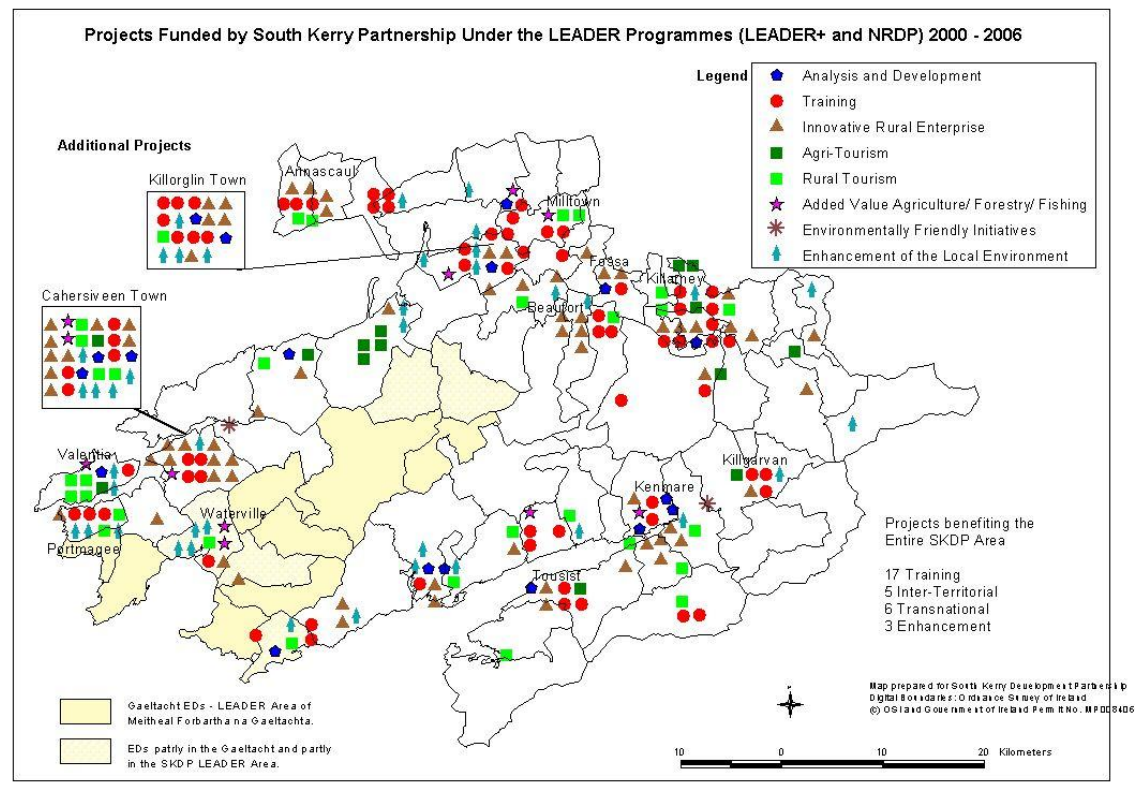




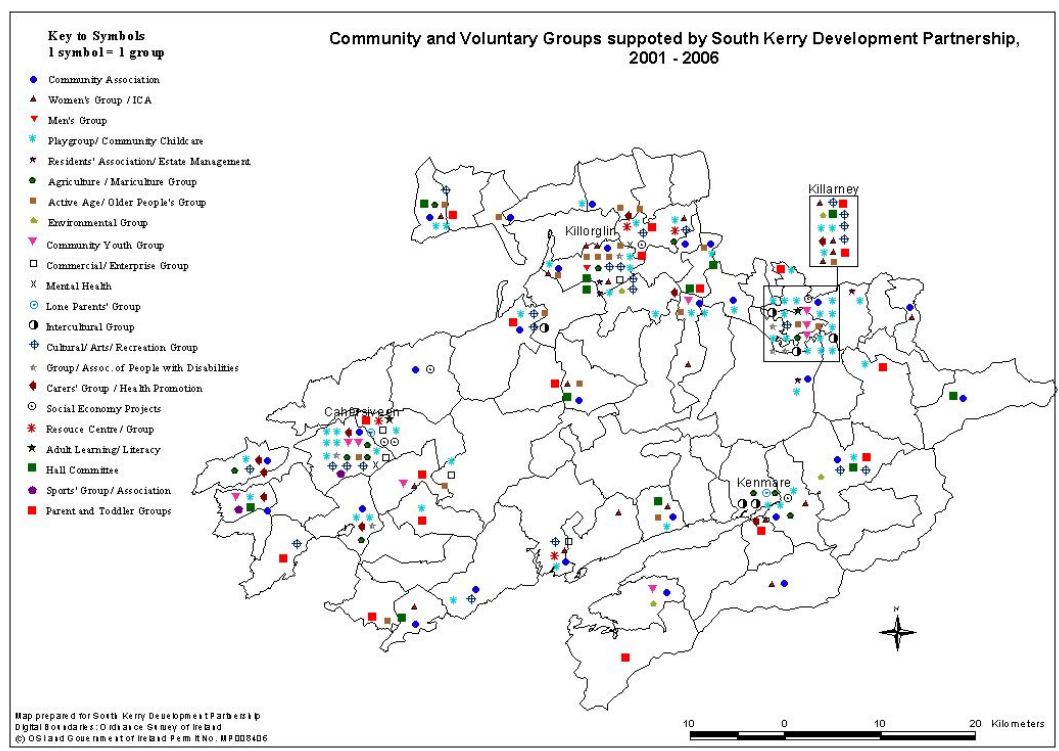

Partnerships are effective in the area of economic development. They are promoting economic diversification, particularly in rural areas, and are supporting and fostering creativity and entrepreneurship. The training and employment programmes delivered by partnerships are enhancing employability, and partnerships are having considerable successes in addressing social exclusion through their employment support actions. Global grant arrangements, multisectoral approaches and a harnessing of local knowledge and expertise favour local economic development.

Partnerships' contributions to the attainment of all dimensions of sustainable development (economic, socio-cultural and environmental) associate positively with on-going monitoring and evaluation; quantitative and qualitative, multiannual, multi-sectoral and integrated strategic planning and programme delivery, inter-partnership networking and collaboration, promotive approaches to animation and idea-generation, strong leadership among partnership directors, management capacity and a coherent territorial approach.

Of the three dimensions of sustainable development, the one that currently requires greatest attention is the natural environment. Partnerships have limited resources and expertise in this area. Despite their implementation of some innovative conservation and ecological projects, there is considerable room for furthering the contribution of local development to the attainment of sustainable 
development goals. Inter-agency collaboration on ecological initiatives needs to be encouraged.

The conclusions from the various case study analyses provide evidence that vindicates the proposals put forward in 2004, by the then EU Commissioner for Agriculture Franz Fischler, when he recommended that at least $7 \%$ of EU Rural Development Funds be allocated to LEADER-type approaches, and that all rural development actions should incorporate a LEADER element. The subsequent decision by the European Council (July 2005) that LEADER should account for at least $5 \%$ of the rural development budget post-2006 represents a significant acknowledgement at EU-level of the achievements of partnership and the potential benefits that can accrue to territories from the mainstreaming of partnership processes. The case study findings from extensive empirical work in Ireland also support the recommendations made by ESPON (ESPON, 2003) and the Rural Economy Foresight Group ${ }^{3}$ that greater levels of resources be transferred from the first to the second pillar of the Common Agricultural Policy.

\section{Conclusion - the way forward for partnership}

Extensive studies of partnership processes, outputs and limitations in Ireland and throughout the EU (OECD, 2006) reveal a number of limitations in the current degree of synergy between partnership and mainstream approaches. That EUlevel commitments to mainstreaming have been put in place, does not automatically mean that similar principles will apply at national level (Storey, 2004). Through their participation in National Social Partnership structures, partnership stakeholders will need to demonstrate their capacity to adapt to emerging development issues, promote further innovation, enable mainstreaming and deliver a broader range of interventions.

Emerging developmental approaches to the provision of social welfare and public services increasingly involve "new forms of public-voluntary and public-private partnerships... and the possibility for local actors of greater autonomy and security in funding" (NESC, 2005) Such economic and institutional evolution requires local development partnerships to fine-tune their ability to target services, articulate local needs and incorporate participative approaches into the delivery of local services. Douglas demonstrates the significance of local and municipal government in rural development. He notes the relevance in rural development terms, of intersections between national, regional and local government systems and arenas and the consequent need for rural development practitioners and stakeholders to be co-ordinated and pro-active in bringing the principles of local democracy to bear on all levels of governance (Douglas, 2006: 112-132). Increasingly, commentators are beginning to recognise and advocate the role of community development and social capital in promoting territorial competitiveness, social cohesion, economic equality and safer societies. Former 
Taoiseach (Irish Prime Minister) Bertie Ahern T.D. has argued that, "the quality of life in society, and the ultimate health of our communities depends on the willingness of people to become active and involved" (address to The Wheel, $14^{\text {th }}$ April 2005). King notes that, "Ireland as both a political and social entity is not immune from the trend to individualisation." However, community development interventions can address this trend (King, 2004). Thus, a renewed emphasis on social inclusion, an operationalisation of equality-proofing and the advocacy of clear endogenous approaches to development are required in future approaches to local development.

The OECD (OECD, 2005) outlines the role local development partnership can and ought to play in fostering cultural development, the arts and entrepreneurship. It advocates the development of "decentralised decision-making framework[s] where local stakeholders can debate the issues among themselves and with central authorities. Von Schomberg is among the commentators, who argue for new approaches to ensuring the attainment of environmental goals in the context of sustainable development (Von Schomberg, 2002).

Thus, new and emerging variables offer partnerships the opportunity to expand and enhance their roles in rural and local development and the realisation of territorial competitiveness. A localised area-based remit, broadly-based membership, high levels of citizen participation, inclusive decision-making processes, multi-sectoral and integrated interventions and commitments to social inclusion are among the defining characteristics of partnership that contribute to sustainable local development.

\section{Notes}

${ }^{1}$ LEADER (Liaison entre Actions de Développement de l'Economie Rurale) is an EU initiative to promote rural development.

2 NESC - National Economic and Social Council, New Approaches to Rural Development. NESC, Dublin, 1994.

3 Rural Economy Foresight Group, Rural Ireland 2025. Maynooth: NUI Maynooth and Teagasc. 2005. 


\section{References}

Contact Point (2007) "Special Focus-Governance in Leader." Leader Magazine. European Commission.

Douglas, D. J. A. (2006)Rural Regional Development Planning: Governance and Other Challenges in the New EU, Studia Regionalia, 18, pp. 112-132.

ESPON European Spatial Planning Observation Network (2003) ESPON Project 2.1.3 -The Territorial Impact of CAP and Rural Development Policy, Third Interim Report, August 2003 (Luxembourg: ESPON).

Fox, C. (2004) 'Strengthening Rural Communities: Quality of Life in Rural Areas with Particular Reference to the Role of Social Capital and Gender Equality Issues' presentation to Ireland 2004 presidency of the European Union conference on Improving living conditions and Quality of Life in Rural Europe. Westport, 30th May - 1'st June 2004. (Department of Community, Rural and Gaeltacht Affairs).

Greer, J., (1999) Partnerships and Public Policy: a Northern Ireland Perspectives on the Interaction between Conditions and Performance, Unpublished thesis, submission for D/Phil (Belfast: Faculty of Business and Management of the University of Ulster, School of Public Policy, Economics and Law).

Greer, J. \& Murray, M. (2003) Rural Planning and Development in Northern Ireland (Dublin: Institute of Public Administration).

King, P. (2004) Relying on the few? A study of Voluntary and Community Participation in County Clare, (Co. Clare: Rural Resource Development. Shannon, Ireland).

NESC - National Economic and Social Council (1994) New Approaches to Rural Development. (Dublin, NESC).

NESC - National Economic and Social Council (2005) The developmental welfare state (Dublin, National Economic and Social Council).

OECD - Organisation for Economic Co-Operation and Development (2001) Better Partnerships for Local Governance (Paris, OECD).

OECD - Organisation for Economic Co-Operation and Development (2005) Culture and Local Development (Paris, OECD).

OECD - Organisation for Economic Co-Operation and Development (2006) The New Rural Paradigm: Policies and Governance (Paris: OECD).

ÖIR Managementdienste GmbH, Methods for and Success of Mainstreaming LEADER Innovations and Approaches into Rural Development Programmes. Final Report Executive Summary. Commissioned by: European Commission DG Agriculture, Unit G4. Vienna. 2004.

O'Keeffe, B. (2006) The Contributions and Limitations of Partnership Processes in Rural Development. Unpublished PhD Thesis (Maynooth: NUI Maynooth, Department of Geography).

Rural Economy Foresight Group (2005) Rural Ireland 2025 (Dublin: NUI Maynooth and Teagasc).

Scott, M. (2004) Building Institutional Capacity in Rural Northern Ireland: the role of partnership governance in the LEADER II programme, Journal of Rural Studies, 20(1) pp. 49-59.

Shortall, S \& Shucksmith, M. (1998) Integrated rural development: issues arising form the Scottish experience, European Planning Studies, 6(1) pp. 73-88.

Shucksmith, M., (2004) Understanding Networks and Social Capital in European Rural Development" presentation to Ireland 2004 presidency of the European Union conference on Improving living Conditions and Quality of Life in Rural Europe. Westport, 30th May $-1^{\text {st }}$ June 2004. (Westport: Department of Community, Rural and Gaeltacht Affairs). 
Storey, A. (2004) 'The European Project: Dismantling Social Democracy, Globalising Neoliberalism' paper presented at the conference Is Ireland a Democracy? $2^{\text {nd }}$ and $3^{\text {rd }}$ April 2004 (Maynooth: NUI Maynooth,. Sociology Department).

Von Schonberg, R. (2002) The Objective of Sustainable Development: Are we coming closer? Foresight Working Papers Series no. 1. (Brussels: European Commission Directorate General for Research, Unit K-2 Science and Technology Foresight).

Walsh, J.A. \& Meldon, J. (eds.) (2004) Partnerships for Effective Local Development. (Charleroi: Université Libre de Bruxelles). 